\title{
DESAIN SKIMMER BOAT (KAPAL PENGAMBIL SAMPAH) DAERAH PERAIRAN SUNGAI DI KALIMANTAN TIMUR
}

\author{
Design of Trash Skimmer Boat for Inland Waterways in East Kalimantan \\ Amalia Ika Wulandari $^{1}$, Wira Setiawan ${ }^{1}$, Taufik Hidayat ${ }^{1}{\text { dan Arman } \text { Fauzi }^{1}}^{1}$ \\ ${ }^{1}$ Institut Teknologi Kalimantan, Balikpapan \\ Email: amaliaikaw@lecturer.itk.ac.id
}

Diterima: 12 April 2020; Direvisi: 19 Mei 2020; Disetujui: 08 Juni 2020

\begin{abstract}
Abstrak
Jumlah sampah yang dibawa ke Tempat Pembuangan Akhir (TPA) Manggar Balikpapan saat ini mencapai $305 \mathrm{~m}^{3}$ per harinya. Lebih dari itu, sering pula dijumpai sampah-sampah yang masih tersebar di muara-muara sungai, pelabuhan, dan kawasan perairan lain yang tidak diketahui jumlahnya, salah satunya di Sungai Klandasan Ilir. Maka masalah yang muncul adalah bagaimana mendesain suatu kapal yang dapat mengatasi penumpukan sampah di perairan sungai dan berapa ukuran utama yang sesuai untuk perairan sungai di Kalimantan. Solusi yang dapat digunakan untuk mengatasi penumpukan sampah yang ada di sungai yaitu dengan menggunakan bantuan Trash Skimmer Boat. Work Boat ini adalah salah satu jenis dari kapal khusus yang difungsikan untuk melakukan pengambilan sampah perairan baik sungai, danau, laut, maupun kanal. Dengan menggunakan metode Parent Design Approach dan bantuan Software Maxsurf, maka diperoleh ukuran utama sebesar LOA = 3 m, B =1,8 m, $\mathrm{T}=0,38 \mathrm{~m}, \mathrm{H}=1,38 \mathrm{~m}$, dan $\mathrm{v}=6$ knot. Bentuk dasar dari Trash Skimmer Boat ini berlambung ponton katamaran yang dilengkapi dengan bak sampah dengan kapasitas $168 \mathrm{~kg}$. Setelah dilakukan survey data sampah, disarankan kapal ini dioperasikan sekali dalam seminggu selama 1 jam dengan fasilitas tambahan yaitu sebuah portable crane.
\end{abstract}

Kata kunci: sampah, sungai, Klandasan Ilir, kapal

\begin{abstract}
The amount of garbage that was taken to the final (TPA) Cage of Balikpapan Manggar reached $305 \mathrm{~m}^{3}$ per day. More than that, often found garbage is still scattered in the estuary of rivers, ports and other waterways that are not known number one on the river Klandasan Ilir. So the problem is how to design a ship that can overcome the buildup of garbage in the river and dimension is suitable for inland waterways in Kalimantan. The solution that can be used to overcome the buildup of garbage in the river is to use the help of Trash Skimmer Boat. One solution to the problem that can be used to overcome the buildup of garbage is held by using the help of Trash Skimmer Boat. This Work Boat is one type of special vessel that is enabled to carry out the water waste, either River, lake, sea or canal. Using the Parent Design Approach and with the help of Software Maxsurf then obtained the main size of $L O A=3 \mathrm{~m}, B=1,8 \mathrm{~m}, T=0,38 \mathrm{~m}, \mathrm{H}=1,38 \mathrm{~m}$, dan $v=6$ knots The basic form of the Trash Skimmer Boat is a catamaran pontoon that is equipped with a garbage bin with a capacity of $168 \mathrm{~kg}$ and
\end{abstract}


Desain Skimmer Boat (Kapal Pengambil Sampah) Daerah Perairan Sungai di Kalimantan Timur

(Amalia Ika Wulandari, Wira Setiawan, Taufik Hidayat dan Arman Fauzi)

after surveying the garbage data, it is recommended that this ship be operated once a week for 1 hour with additional facilities, namely a portable crane.

Keywords: garbage, river, Klandasan Ilir, boat

\section{PENDAHULUAN}

Balikpapan memiliki luas wilayah sekitar $503.3 \mathrm{~km}^{2}$. Kota Balikpapan juga merupakan kota di Kalimantan Timur dengan jumlah penduduk terbesar ketiga setelah Kota Samarinda dan Kabupaten Kutai Kartanegara. Jumlah penduduk Kota Balikpapan tahun 2017 sebanyak 636012 jiwa. Tentu ini menyebabkan tingkat produktivitas sampah yang tinggi setiap harinya di Kota Balikpapan dikarenakan jumlah penduduk yang banyak khususnya di Provinsi Kalimantan (Badan Pusat Statistik Kota Balikpapan, 2018).

Penumpukan sampah menimbulkan bau yang tidak sedap dan cukup mengganggu warga setempat dalam beraktivitas di lingkungan tersebut. Pemerintah melalui Dinas Lingkungan Hidup Balikpapan telah memberikan penanganan berupa gabus apung yang disusun membentuk jembatan tujuannya agar sampah tidak tersebar kemana-mana. Akan tetapi, sampah masih saja terus tersebar bahkan melewati jembatan gabus apung dan warga setempat juga mengaku kesulitan dalam membersihkan sampah yang ada di sungai tersebut. Ini menunjukkan bahwa gabus apung belum menjadi solusi yang dapat menjawab secara keseluruhan permasalahan di sungai tersebut. Di samping itu pula, warga setempat menginginkan adanya sebuah transportasi khusus dalam penanganan masalah sampah di sungai ini.

Berdasarkan uraian di atas maka timbul permasalahan bagaimana mendesain suatu kapal yang dapat mengatasi penumpukan sampah di perairan sungai dan berapa ukuran utama yang sesuai untuk perairan sungai di Kalimantan. Salah satu solusi dari permasalahan yang dapat digunakan untuk mengatasi penumpukan sampah yang ada disungai yaitu dengan menggunakan bantuan trash skimmer boat. Trash skimmer boat adalah salah satu jenis dari kapal khusus di mana kapal ini difungsikan untuk melakukan pengambilan sampah perairan baik perairan sungai, danau, laut, maupun kanal. Bentuk dasar dari trash skimmer boat ini adalah berlambung ponton katamaran. Kapal ini juga dilengkapi dengan bak sampah yang berfungsi sebagai bak penampung untuk mengumpulkan sampah dari perairan (Walezyk, 2006).
Untuk memenuhi kebutuhan akan permintaan atas permasalahan yang telah disebutkan sebelumnya, maka perlu dilakukannya perancangan trash boat yang digunakan untuk mengumpulkan sampah khusus di kawasan Sungai Klandasan Ilir ini guna mengurangi pencemaran lingkungan. Dengan harapan konsep desain dari trash boat yang minimalis dapat menjadi solusi dalam mengurangi banyaknya sampah yang tersebar di lingkungan tersebut.

\section{TINJAUAN PUSTAKA}

\section{Kapal Kerja Skimmer}

Kapal kerja skimmer merupakan kapal khusus yang fungsi dan kerjanya khusus untuk daerah tertentu sehingga desain untuk masing-masing kapal memiliki karakteristik yang berbeda sesuai lokasi pelayaran dan tujuan pembuatan kapal.

\section{Trash Skimmer Boat}

Trash skimmer boat merupakan kapal kerja berlambung ponton katamaran yang berfungsi untuk mengumpulkan sampah yang berada di perairan. Kapal ini dirancang sesuai dengan kebutuhan operasionalnya dan dilengkapi bak penampung yang berfungsi untuk mengumpulkan sampah yang mengapung di pelabuhan dan saluran-saluran air (Walezyk, 2006). Trash skimmer boat ada yang menggunakan conveyor belt dan ada yang tidak, pengoperasian keduanya pun memiliki perbedaan. Sisi haluan pada trash skimmer boat yang berfungsi sebagai pintu masuknya sampah terdapat lengan yang bisa ditutup atau dibuka seperti pintu yang digerakkan dengan sistem hidrolik. Untuk trash skimmer boat yang dilengkapi dengan conveyor belt, conveyor belt tersebut berada di haluan, bisa dinaik-turunkan sesuai kebutuhan. Sampah yang berhasil ditangkap selanjutnya akan dikumpulkan ke dalam bak penampung yang berada di belakang conveyor belt untuk selanjutnya diangkut menuju bak atau truk penampung yang terletak di darat untuk proses pengolahan lebih lanjut. Segala jenis sampah yang berukuran kurang dari lebar conveyor akan terangkat melalui sisi haluan melewati lengan ayun (flexy conveyor) yang kemudian dibawa menuju bak penampung yang terdapat di bagian tengah kapal, di 
antara dua hull ponton. Dan adapun trash skimmer boat tanpa menggunakan conveyor belt memiliki desain yang lebih sederhana jika dibandingkan dengan trash skimmer boat yang memiliki conveyor belt.

Di beberapa tempat di dunia yang telah menggunakan trash skimmer boat antara lain The Cities of Baltimore, Washington, D.C., Fort Lauderdale, New York, Chicago, serta Indonesia. Dalam pengoperasiannya diperlukan 2-3 orang kru untuk menjamin bahwa kapal kerja ini menjalankan fungsinya dengan baik.
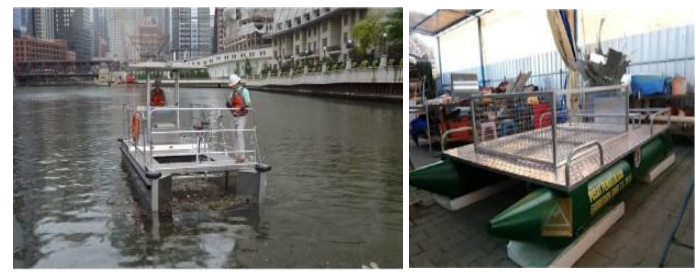

Gambar 1. Trash skimmer boat tanpa menggunakan conveyor belt

Gambar 1 merupakan kapal pengambil sampah yang terbuat dari aluminium dan sangat cocok untuk dioperasikan di sungai, kanal, hingga kali. Prinsip kedua kapal tersebut hampir sama yaitu sampah harus masuk ke dalam bak sampah tanpa menggunakan lengan ayun (flexy conveyor). Akan tetapi kedua kapal di atas tidak memerlukan biaya yang cukup besar dalam pengerjaannya serta desain dari dua kapal di atas lebih sederhana sehingga memudahkan desainer dalam merancang kapal tersebut.

\section{Weed Harvester Skimmer Boat}

Seperti yang ditunjukkan pada Gambar 2 kapal kerja jenis ini berfungsi untuk memotong tumbuhan yang tumbuh di danau atau sungai. Hal tersebut dilakukan untuk mencegah terjadinya pendangkalan pada perairan tersebut sekaligus membersihkan jalur pelayaran. Dikarenakan fungsi itulah kapal kerja jenis ini dilengkapi dengan conveyor belt di mana ujung lengannya diberi alat pemotong. Tumbuhan seperti ganggang dan eceng gondok akan terpotong oleh alat pemotong, kemudian tumbuhan tersebut akan langsung terangkut oleh conveyor belt menuju bak penampung di atas geladak kapal. Kapal ini menggunakan lambung ponton dan menggunakan mesin single diesel engine yang menyuplai kebutuhan propulsi, kelistrikan, dan peralatan hidrolik. Untuk melakukan fungsinya, kapal jenis ini disarankan memiliki olah gerak yang baik. Oleh karena digunakan propeller yang dapat berotasi $360^{\circ}$ untuk mempermudah olah gerak kapal. Peralatan kerja yang ditopang oleh lengan hidrolik adalah pisau potong, front conveyor, propulsi, steering of the boat dan crane. Karena fungsi kerja dan tempat kerja yang spesifik, maka dapat dilakukan modifikasi baja untuk memaksimalkan kinerja kapal.

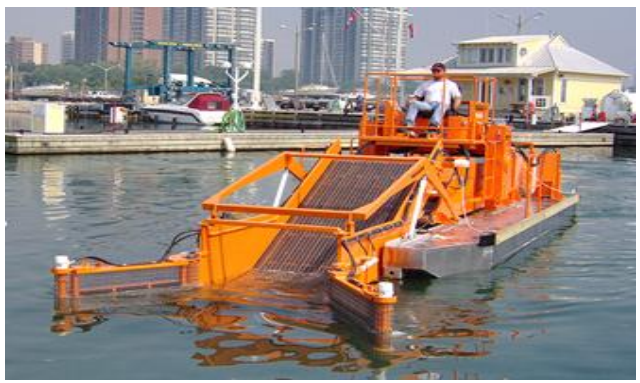

Gambar 2. Weed harvester skimmer boat

\section{Katamaran}

Katamaran merupakan kapal yang mempunyai dua lambung atau badan yang dihubungkan oleh geladak atau bridging platform di tengahnya. Bridging platform ini bebas dari permukaan air, sehingga slamming dan deck wetness kapal dapat dikurangi (Gambar 3). Penentuan ketinggian struktur bagian atas dari permukaan air merupakan fungsi dari tinggi gelombang rute pelayaran yang dilalui. Kombinasi luas geladak yang besar dan berat kapal kosong yang rendah membuat kapal katamaran dapat diandalkan untuk transportasi muatan antar kota maupun pariwisata. Karakter tahanan di air tenang tipe katamaran lebih besar dibandingkan dengan kapal monohull. Dominasi tahanan gesek mencapai $40 \%$ dari tahanan total pada kecepatan rendah. Penurunan kecepatan akibat kondisi gelombang tinggi tidak dijumpai pada kasus katamaran. Kapal tipe ini dapat dioperasikan pada kecepatan relatif tinggi dan masih mempunyai konsumsi bahan bakar yang dapat diterima secara ekonomis.

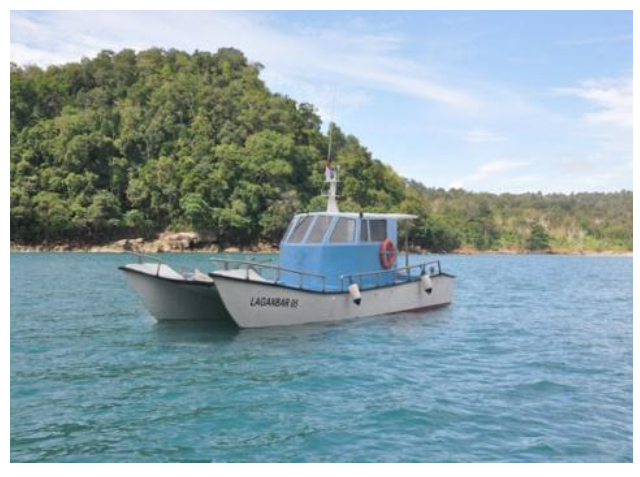

Gambar 3. Kapal katamaran 
Desain Skimmer Boat (Kapal Pengambil Sampah) Daerah Perairan Sungai di Kalimantan Timur

(Amalia Ika Wulandari, Wira Setiawan, Taufik Hidayat dan Arman Fauzi)

Bentuk badan kapal harus dipilih berdasarkan metode yang tepat sehingga hasilnya akan didapatkan hasil yang memuaskan. Kapal katamaran dengan geladak yang lebih besar adalah salah satu contoh konsep rancangan yang berhasil dalam mengatasi efek gerakan oleng, dimana gerakan oleng tersebut merupakan kelemahan utama kapal-kapal konvensional atau monohull (Arianto, 2016).

\section{Tipe Kapal Katamaran}

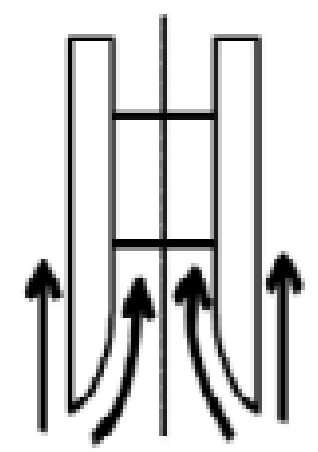

Gambar 4. "Type A" flat side outside

(Chrismianto dkk., 2014)

Type A (Gambar 4) mempunyai bentuk badan kapal asimetris Flat Side Outside. Dimana lambung kapal memiliki bidang datar di luar dan bidang streamline di dalam. Aliran fluida yang dibentuk dari haluan kapal terkonsentrasi di tengah kapal (antara lambung) bergerak sampai ke buritan kapal, sedangkan ke arah samping arah aliran lurus mengikuti bentuk badan kapal sisi luar sampai ke buritan.

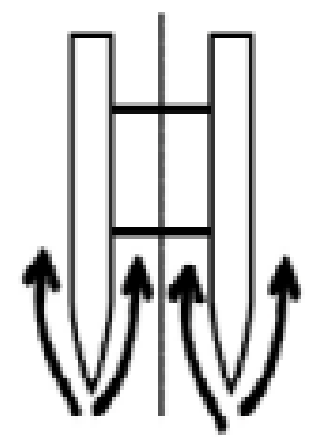

Gambar 5. "Type B" simetris (Chrismianto dkk., 2014)

Type B (Gambar 5) mempunyai bentuk badan kapal simetris. Dimana kedua lambung kapal memiliki bidang streamline di dalam maupun di luar lambung. Diasumsikan sebagaimana dua buah kapal monohull yang kedua lambungnya dihubungkan dengan jarak tertentu, maka akan mempunyai sistem gelombang yang sama dengan bentuk kapal streamline. Pada sekeliling bagian kapal yang tercelup dalam air akan berkembang dan menghasilkan gerakan. Hal ini akan menimbulkan dua macam gelombang, yaitu gelombang divergen dan gelombang transversal. Kedua gelombang ini secara umum terdapat di bagian dekat haluan dan buritan kapal yang bergerak ke depan bersama badan kapal.

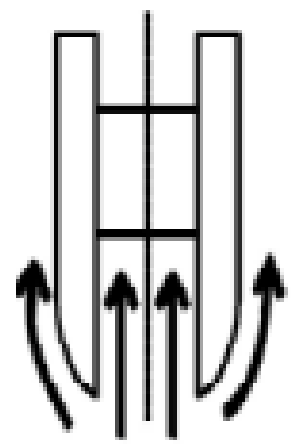

Gambar 6. "Type C" flat side inside

(Chrismianto dkk., 2014)

Type C (Gambar 6) mempunyai bentuk badan kapal asimetris flat side inside, dimana lambung kapal memiliki bidang datar di dalam dan bidang streamline di luar. Di ujung bagian depan demihull merupakan titik di mana aliran fluida akan menyebar ke arah samping (mengikuti garis streamline) dan di bagian sisi dalam lurus sehingga alirannya mengikuti bentuk badan kapal (lurus) sampai ke buritan kapal. Sehingga apabila diterapkan bentuk ini akan menimbulkan gelombang ke samping yang cukup besar.

\section{Metode Desain Kapal}

Parent design approach merupakan salah satu metode dalam mendesain kapal dengan cara perbandingan atau komparasi, yaitu dengan cara mengambil sebuah kapal yang dijadikan sebagai acuan kapal pembanding yang memiliki karakteristik yang sama dengan kapal yang akan dirancang. Dalam hal ini designer sudah mempunyai referensi kapal yang sama dengan kapal yang akan dirancang, dan terbukti mempunyai performa yang bagus. Keuntungan dalam parent design approach adalah:

- Dapat mendesain kapal lebih cepat, karena sudah ada acuan kapal sehingga cukup dilakukan modifikasi;

- Performa kapal telah teruji dari segi stabilitas, motion dan resistance. 


\section{Perhitungan Resistance}

Tujuan dari perhitungan hambatan total kapal adalah untuk menentukan kebutuhan daya mesin yang sesuai pada kapal. Dengan demikian kapal dapat beroperasi dengan kecepatan sebagaimana yang sesuai dengan owner requirement. Untuk menghitung hambatan kapal. Dalam penelitian Insel \& Molland (1991), hambatan kapal dipengaruhi oleh besarnya nilai WSA kapal dan koefisien hambatan total kapal $\left(\mathrm{C}_{\text {tot }}\right)$.

Komponen hambatan yang dialami oleh katamaran lebih kompleks dikarenakan adanya efek interferensi antar kedua lambungnya, yaitu:

1. Viscous interference resistance (interferensi viskositas) adalah aliran di sepanjang demihull simetris berbentuk tidak simetris akibat pengaruh keberadaan demihull.

2. Wave making intererence resistance (interferensi gelombang) adalah hasil dari dua buah lambung yang bergerak sejajar, efek interferensi pada hambatan gelombang akan sangat berpengaruh. Hambatan total pada katamaran harus dikalikan dua, mengingat katamaran memiliki dua lambung yang identik. Dalam paper Insel \& Molland rumus tahanan total untuk tiap lambung kapal katamaran adalah sebagai berikut:

$$
C_{\text {tot }}=(1+\beta k) \times C F+\tau C W
$$

Dimana,

$$
\begin{aligned}
(1+ß \mathrm{k})= & \text { catamaran viscous resistance } \\
& \text { interference } \\
\mathrm{CF} \quad= & \text { friction resistance } \\
\tau & =\text { catamaran wave resistance interference } \\
\mathrm{CW} \quad= & \text { wave resistance }
\end{aligned}
$$

Di dalam percobaannya menghitung harga hambatan total, Insel \& Molland (1991) mengasumsikan kapal katamaran dengan kapal demihull yang ditambahkan dengan harga interferensi yang diakibatkan oleh lambung yang berjarak $S$ dari center line-nya. Harga dari hambatan total ini tetap dikalikan 2 mengingat luas permukaan basah (WSA) ada pada tiap lambung. Hambatan total dapat dihitung dengan formula di bawah ini.

$$
R T=0.5 \times \rho 2 \times W S A \times v^{2} \times C_{t o t}
$$

Dimana,

$\rho \quad=$ massa jenis fluida $\left(\mathrm{kg} / \mathrm{m}^{3}\right)$

WSA = luas permukaan badan kapal yang tercelup air $\left(\mathrm{m}^{2}\right)$ $\mathrm{v} \quad=\operatorname{kecepatan} \operatorname{kapal}(\mathrm{m} / \mathrm{s})$

Ctot $=$ koefisien hambatan total katamaran

Dalam perhitungan ini hambatan total yang dihitung adalah untuk kecepatan maksimal kapal $\left(\mathrm{v}_{\max }\right)$. Hal ini dilakukan untuk mengetahui besarnya hambatan total yang terjadi saat kapal berlayar dengan full speed serta untuk menentukan besarnya daya mesin maksimal yang digunakan nantinya.

Hambatan dihitung pada Froude Number $(\mathrm{Fr})=0.402$. Sehingga didapat kecepatan model dengan skala 1:10 didapat kecepatan $(\mathrm{v})=3.044 \mathrm{~m} / \mathrm{s}$. Rumus empiris hambatan total:

$$
R T=\frac{1}{2} W S A \times V^{2} \times \rho \times C t \times 2
$$

Insel \& Molland (1991) mengajukan ekspresi persamaan untuk hambatan total katamaran:

$$
C_{T C A T}=(1+\beta k) \times C F+\tau C W
$$

Kemudian faktor interferensi viskos tersebut diformulasikan lagi oleh Jamaluddin dkk. (2012) sebagai berikut:

$$
\begin{aligned}
(1+\beta \mathrm{k}) & =3.03(\mathrm{Lwl} / \mathrm{V} 1 / 3)-0.40+0.016(\mathrm{~S} / \mathrm{L})-0.65 \\
(1+\beta \mathrm{k}) & =3.03(6 / 1.4(1 / 3))-0.40+0.016(0.2)-0.65 \\
& =2.358
\end{aligned}
$$

Dimana,

Lwl = Panjang garis air model kapal (m)

$\mathrm{V} \quad=$ Volume displacement $\left(\mathrm{m}^{3}\right)$

Untuk perhitungan CF dan CW kapal dapat dilihat dibawah ini:

$$
\begin{array}{ll}
\mathrm{CF} & =0.014 \\
\mathrm{CW} & =0.368
\end{array}
$$

Kemudian Perhitungan $\tau$ (faktor gelombang) menggunakan tabel formulasi dibawah ini dimana interferensi komponen hambatan gelombang bergantung pada Froude Number (Jamaluddin dkk., 2012).

$$
\begin{array}{ll}
\tau=0.068(\mathrm{~S} / \mathrm{L})-1.38 & (\text { pada } \mathrm{Fr}=0.19) \\
\tau=0.359(\mathrm{~S} / \mathrm{L})-0.87 & (\text { pada } \mathrm{Fr}=0.28) \\
\tau=0.574(\mathrm{~S} / \mathrm{L})-0.33 & (\text { pada } \mathrm{Fr}=0.37) \\
\tau=0.790(\mathrm{~S} / \mathrm{L})-0.14 & (\text { pada } \mathrm{Fr}=0.47) \\
\tau=0.504(\mathrm{~S} / \mathrm{L})-0.31 & (\text { pada } \mathrm{Fr}=0.56) \\
\tau=0.501(\mathrm{~S} / \mathrm{L})-0.18 & (\text { pada } \mathrm{Fr}=0.65)
\end{array}
$$

Froude Number (Fn) yang digunakan sebagai variasi kecepatan adalah 0.65 : 
Desain Skimmer Boat (Kapal Pengambil Sampah) Daerah Perairan Sungai di Kalimantan Timur (Amalia Ika Wulandari, Wira Setiawan, Taufik Hidayat dan Arman Fauzi)

$$
\tau=1.02 \quad(\text { pada } \mathrm{Fr}=0,40)
$$

Ditentukan melalui interpolasi. Sehingga persamaan 1 Koefisien Total untuk Froude Number 0.65 yaitu:

$$
\begin{aligned}
\mathrm{CT} 1 & =(1+\beta \mathrm{K}) \mathrm{CF}+\tau \mathrm{CW} \\
& =2.672 \times 0.002+0.98 \times 0.060 \\
& =0.377
\end{aligned}
$$

Kemudian persamaan hambatan total untuk Froude Number 0.65 yaitu:

$$
R T=\frac{1}{2} \times 2 \times W S A \times V^{2} \times \rho \times C t
$$

\section{METODE PENELITIAN}

Penelitian yang dilakukan adalah berupa perancangan. Perancangan yang dilakukan adalah dengan mendesain suatu kapal pengangkut sampah dengan lambung katamaran. Pada perancangan ini ukuran utama kapal pengangkut sampah diambil dari kapal pembanding yang telah eksis sebelumnya. Setelah kapal pengangkut sampah selesai dirancang, maka dilakukan perhitungan hambatan kapal. Untuk mendapatkan ukuran utama kapal, sebelum mendesain dikumpulkan beberapa ukuran kapal pembanding yang nantinya akan dihitung untuk mendapatkan ukuran utama kapal yang terbaik. Setelah didapatkan ukuran utama, dimulailah perhitungan hambatan, besar daya mesin, serta berat kapal. Pada penelitian berupa perancangan ini digunakan beberapa software untuk menunjang proses perancangan. Software yang digunakan meliputi :

1. Maxsurf Modeler 12 Version

Software Maxsurf digunakan untuk memodelkan trash skimmer boat. Hasil dari perancangan dengan software ini adalah model kapal disertai dengan karakteristik hidrostatis kapal dan rencana garis kapal.

2. AutoCAD 2018 Student Version

Software AutoCAD digunakan untuk memperhalus gambar rencana garis dari Maxsurf dan untuk menggambar rencana umum trash skimmer boat.

\section{PEMBAHASAN}

\section{Data Sungai}

Sungai Klandasan Ilir merupakan sungai yang melewati kawasan Klandasan di Kota Balikpapan. Sungai ini berada di salah satu tempat wisata Kota Balikpapan yaitu Kampung Warna-Warni Phinisi Klandasan Ilir. Kondisi sungai ini cukup memprihatinkan dikarenakan sering kali terjadi banyak penumpukan sampah sehingga menimbulkan rasa tidak nyaman warga Kampung Pinisi yang tinggal di sekitar sungai tersebut. Sungai ini memiliki ukuran seperti terlihat pada Tabel 1 .

Tabel 1 Dimensi Sungai Klandasan Ilir

Dimensi Sungai Klandasan Ilir

\begin{tabular}{cc}
\hline Panjang & $1.357 \mathrm{~km}$ \\
Kedalaman & $2.150 \mathrm{~m}$ \\
Lebar & $5.000 \mathrm{~m}$ \\
\hline
\end{tabular}

(Sumber: Badan Lingkungan Hidup (2015))

\section{Data Sampah}

Dalam menentukan payload kapal ini, dilakukan pengambilan data secara primer yaitu menghitung volume total sampah di sungai selama 8 hari berturut-turut dengan 2 kondisi yang berbeda maka diperoleh rata-rata sampah $15.1 \mathrm{~kg} / \mathrm{hari}$

\section{Penentuan Ukuran Utama}

Menentukan ukuran utama kapal dengan menggunakan metode parent design approach yaitu metode dengan menggunakan kapal pembanding yang memiliki karakteristik yang sama dengan kapal yang akan penulis rencanakan. Kapal pembanding yang digunakan sebagai acuan harus terbukti memiliki performa yang baik. Dalam mekanismenya dilaksanakan dengan cara mengambil data sebuah kapal yang telah beroperasi dan dijadikan sebagai acuan. Dengan menggunakan metode ini penulis telah memiliki referensi kapal yang sama dengan kapal yang didesain sehingga proses mendesain dapat lebih cepat dilakukan dan hanya menambahkan beberapa modifikasi sesuai dengan kebutuhan. Selain itu penulis juga telah memiliki gambaran yang lebih jelas tentang performa kapal yang menjadi acuan karena telah terbukti dapat beroperasi dengan baik. Sehingga data kapal yang didapatkan digunakan sebagai acuan, tidak menggunakan analisa regresi linier dalam menentukan ukuran utama kapal.

Kapal pembanding adalah Kapal Pembersih Sungai 3 M. Kapal ini beroperasi saluran-saluran air di kota Yogyakarta. Sehingga kapal ini difungsikan tidak hanya untuk mengatasi banyaknya sampah rumah tangga tapi juga sampah terapung lainnya yang berada pada saluran air ini. Berikut merupakan data kapal Kapal Pembersih Sungai 3 M yang telah diperoleh oleh penulis. Data kapal tersebut dapat 
dilihat pada Tabel 2.

Berdasarkan data yang telah didapatkan dari kapal acuan, ukuran utama awal kapal ditentukan seperti terlihat pada Tabel 3 .

Tabel 2. Data kapal pembanding

\begin{tabular}{llc}
\hline Nama kapal & $:$ & Kapal Pembersih Sungai 3 M \\
Panjang kapal (L) & $:$ & $3 \mathrm{~m}$ \\
Lebar kapal (B) & $:$ & $1.8 \mathrm{~m}$ \\
Tingi kapal (H) & $:$ & $1.38 \mathrm{~m}$ \\
Sarat kapal (T) & $:$ & $0.38 \mathrm{~m}$ \\
Kapasitas keranjang & $:$ & $168 \mathrm{~kg}$ \\
sampah & & \\
\hline
\end{tabular}

Dengan menggunakan rasio ukuran utama maka data kapal pembanding diambil sebagai data kapal yang akan digunakan Data tersebut digunakan sebagai data kapal saat perancangan model kapal di software Maxsurf (Gmabar 7).

Tabel 3. Rasio ukuran utama kapal

\begin{tabular}{rrr}
\hline $\mathrm{L} / \mathrm{B}$ & $:$ & 2.0 (range $2-30)$ \\
$\mathrm{B} / \mathrm{T}$ & $:$ & 4.7 (range $4.2-7.78)$ \\
$\mathrm{H} / \mathrm{T}$ & $:$ & $3.5($ range $1.36-3.65)$ \\
\hline
\end{tabular}

(Sumber: Dubrovsky dan Lyakhovitsky (2001))

Tabel 4. Hasil perhitungan hidrostatik pada software Maxsurf Modeler

\begin{tabular}{|c|c|c|c|}
\hline No & Measurements & Value & Unit \\
\hline 1 & Displacement & 0.697 & $\mathrm{t}$ \\
\hline 2 & Volume (displaced) & 0.697 & $\mathrm{~m}^{\wedge} 3$ \\
\hline 3 & Draft Amidships & 0.370 & $\mathrm{~m}$ \\
\hline 4 & Immersed depth & 0.370 & $\mathrm{~m}$ \\
\hline 5 & WL Length & 3.000 & $\mathrm{~m}$ \\
\hline 6 & Beam max extents on WL & 2.000 & $\mathrm{~m}$ \\
\hline 7 & Wetted Area & 5.962 & $\mathrm{~m}^{\wedge} 2$ \\
\hline 8 & Max sect. area & 0.274 & $\mathrm{~m}^{\wedge} 2$ \\
\hline 9 & Waterpl. Area & 2.325 & $\mathrm{~m}^{\wedge} 2$ \\
\hline 10 & Prismatic coeff. (Cp) & 0.850 & \\
\hline 11 & Block coeff. (Cb) & 0.314 & \\
\hline 12 & Max Sect. area coeff. $(\mathrm{Cm})$ & 0.370 & \\
\hline 13 & Waterpl. area coeff. (Cwp) & 0.388 & \\
\hline 14 & LCB length & 1.291 & from zero pt. (+ve fwd) $m$ \\
\hline 15 & LCF length & 1.325 & from zero pt. (+ve fwd) $m$ \\
\hline 16 & LCB $\%$ & 43.030 & from zero pt. (+ve fwd) $\% \mathrm{Lwl}$ \\
\hline 17 & LCF $\%$ & 44.163 & from zero pt. (+ve fwd) $\% \mathrm{Lwl}$ \\
\hline 18 & $\mathrm{~KB}$ & 0.207 & $\mathrm{~m}$ \\
\hline 19 & KG fluid & 0.000 & $\mathrm{~m}$ \\
\hline 20 & BMt & 2.140 & $\mathrm{~m}$ \\
\hline 21 & BML & 2.024 & $\mathrm{~m}$ \\
\hline 22 & GMt corrected & 2.347 & $\mathrm{~m}$ \\
\hline 23 & GML & 2.231 & $\mathrm{~m}$ \\
\hline 24 & $\mathrm{KMt}$ & 2.347 & $\mathrm{~m}$ \\
\hline 25 & KML & 2.231 & $\mathrm{~m}$ \\
\hline 26 & Immersion (TPc) & 0.023 & tonne $\mathrm{cm}$ \\
\hline 27 & MTc & 0.005 & tonne.m \\
\hline 28 & RM at 1 deg $=$ GMt.Disp. $\sin (1)$ & 0.029 & tonne.m \\
\hline 29 & Length:Beam ratio & 1.500 & \\
\hline 30 & Beam:Draft ratio & 5.405 & \\
\hline 31 & Length: $\mathrm{Vol}^{\wedge} 0.333$ ratio & 3.383 & \\
\hline 32 & Precision & High & 58 stations \\
\hline
\end{tabular}

Dengan bentuk lambung flat side outside ini juga sesuai dengan kebutuhan karena tidak memerlukan geladak yang besar. Selain itu aliran fluida akan terkonsentrasi di tengah kapal sehingga memudahkan dalam proses pengumpulan sampah. Adapun data hasil running pada kapal dapat dilihat pada Tabel 4.

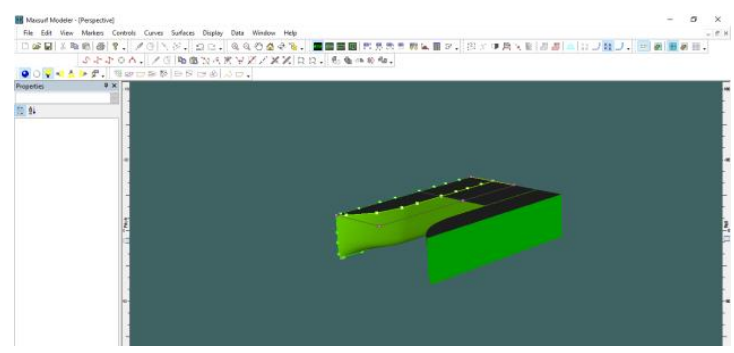

Gambar 7. Pemodelan ukuran utama pada software Maxsurf Modeler

\section{Penentuan Daya Mesin}

Setelah didapatkan ukuran utama kapal serta desain lines plan, langkah selanjutnya yang dilakukan adalah melakukan perhitungan awal. Perhitungan awal meliputi perhitungan Froud Number, perhitungan coefficient $(\mathrm{Cb}, \mathrm{Cm}, \mathrm{Cp}$, dan $\mathrm{Cwp})$, displacement, dan volume displacement. Dalam subbab ini akan dijelaskan perhitungan perencanaan mesin pada kapal Trash Skimmer Boat.

\section{Hasil Simulasi dan Nilai Hambatan Kapal Katamaran dengan Software Maxsurf Resistance}

Dengan menggunakan formula yang sama diperoleh juga nilai hambatan dalam beberapa kecepatan seperti pada Tabel 5 di bawah ini:

Tabel 5. Perbandingan 5 variasi kecepatan

\begin{tabular}{lllllll}
\hline \multicolumn{7}{c}{ PERBANDINGAN 5 KECEPATAN } \\
\hline $\mathrm{v}$ & 3 & 4 & 5 & 6 & 7 & $\mathrm{Knot}$ \\
\cline { 2 - 7 } & 1.54 & 2.06 & 2.57 & 3.09 & 3.60 & $\mathrm{~m} / \mathrm{s}$ \\
\hline $\mathrm{fn}$ & 0.28 & 0.38 & 0.47 & 0.57 & 0.66 & \\
$\mathrm{Rn}$ & 0.000 & 0.000 & 0.000 & 0.000 & 0.000 & \\
$1+\mathrm{bK}$ & 2.350 & 2.350 & 2.350 & 2.350 & 2.350 & \\
$\mathrm{t}$ & 0.124 & 0.281 & 0.926 & 1.016 & 0.926 & \\
$\mathrm{Cf}$ & 0.001 & 0.001 & 0.001 & 0.001 & 0.002 & \\
$\mathrm{cw}$ & 0.368 & 0.368 & 0.368 & 0.368 & 0.368 & \\
$\mathrm{Cttotal}$ & 0.049 & 0.107 & 0.344 & 0.377 & 0.344 & \\
$\mathrm{RT}$ & 59.718 & 231.900 & 1168.968 & 1845.757 & 2292.130 & $\mathrm{~N}$ \\
& 0.060 & 0.232 & 1.169 & 1.846 & 2.292 & $\mathrm{kN}$ \\
$\mathrm{RT}$ & 0.069 & 0.267 & 1.344 & 2.123 & 2.636 & $\mathrm{kN}$ \\
& & & & & & \\
\hline
\end{tabular}

Perhitungan power kapal dilakukan dengan mencari nilai EHP terlebih dahulu, lalu sesudah mendapatkan EHP dilakukan perhitungan DHP dari perhitungan DHP didapatkan perhitungan BHP. Di mana nilai BHP tersebut yang dipakai untuk mencari mesin induk kapal yang sesuai dengan performa kapal. Pemilihan mesin induk harus sesuai dengan BHP yang sudah dihitung. 
Desain Skimmer Boat (Kapal Pengambil Sampah) Daerah Perairan Sungai di Kalimantan Timur (Amalia Ika Wulandari, Wira Setiawan, Taufik Hidayat dan Arman Fauzi)

Dengan menggunakan formula yang sama diperoleh juga nilai BHP dalam beberapa kecepatan dapat ditinjau pada Tabel 6 di bawah ini:

Tabel 6. Perhitungan dengan berdasarkan variasi 5 kecepatan

\begin{tabular}{lrrrrrr}
\hline Kecepatan & 3 & 4 & 5 & 6 & 7 & Vs \\
\cline { 1 - 5 } EHP Empiris & 0.105 & 0.548 & 3.457 & 6.551 & 9.491 & $\mathrm{HP}$ \\
\cline { 1 - 3 } DHP Empiris & 0.082 & 0.424 & 2.676 & 5.070 & 7.346 & $\mathrm{HP}$ \\
\cline { 1 - 5 } BHP Empiris & 0.094 & 0.488 & 3.077 & 5.831 & 8.448 & $\mathrm{HP}$ \\
\hline
\end{tabular}

\section{Pemilihan Mesin Induk}

Pemilihan mesin induk dilakukan dengan mempertimbangkan berat mesin, daya mesin dan harga mesin tersebut. Dari katalog seperti pada tabel 7 yang sudah penulis kumpulkan didapatkan beberapa mesin induk beserta spesifikasinya. Dari katalog mesin Yamaha yang sudah ada, didapatkan mesin kapal beserta spesifikasinya sebagai berikut:

Tabel 7. Katalog mesin outboard Yamaha

\begin{tabular}{lc}
\hline Brand & Yamaha Motor \\
Weight & $60 \mathrm{lb} / 27 \mathrm{~kg}$ \\
Horsepower & 6 \\
Starting System & Manual \\
Recommended Fuel & Unleaded Gasoline (Minium \\
Model & Pump octane 87) \\
Cooling System & Throttle Four Stroke Portable \\
Full & Water, Thermostatic Control \\
Range & 4500-5500 \\
Propeller & Standard \\
Shaft Length & $20 ”$ \\
Lubrication System & Wet sump \\
\hline
\end{tabular}

\section{Desain Kapal}

Rencana garis merupakan gambar pandangan atau gambar proyeksi badan kapal yang dipotong secara melintang (body plan), secara memanjang (sheer plan), dan vertikal memanjang (half breadth plan). Tahap awal dalam perancangan rencana garis ini ialah menentukan pilihan terhadap kapal yang akan digunakan sebagai parent ship. Pertimbangan dalam menentukan parent ship ialah dipilih kapal yang memiliki karakteristik hampir sama dengan karakteristik kapal yang akan kita desain.

Selanjutnya melakukan editing pada beberapa elemen yang meliputi size surface, frame of reference, zero point serta menambahkan surface yang dibutuhkan. Keluaran yang didapatkan melalui software Maxsurf Modeler berupa body plan, sheerplan dan half breadth plan kapal dalam bentuk .dxf. Selanjutnya, gambar tersebut kemudian digabungkan menjadi satu dengan software AutoCad serta dapat dilakukan editing pada ketiga gambar tersebut.

Gambar 8 menunjukkan body plan yang merupakan tampak haluan dan buritan pada kapal. Posisi kapal apabila dilihat secara melintang, dan di dalam body plan terdapat station-station yang merupakan hasil proyeksi dari station-station yang ada pada proyeksi membujur sehingga diproyeksikan ke pandangan melintang.

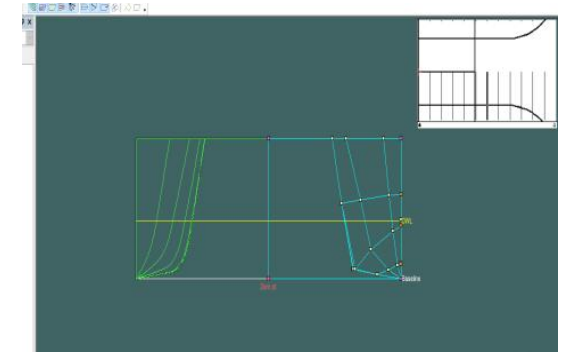

Gambar 8. Body plan trash skimmer boat

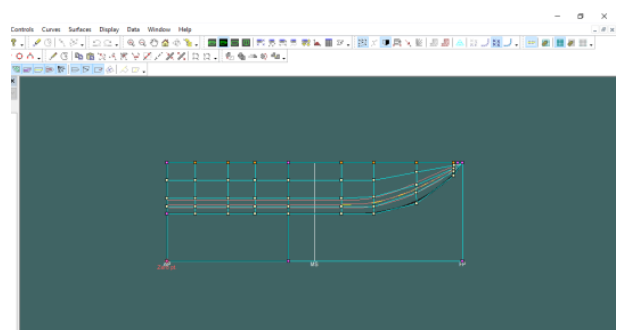

Gambar 9. Half breadth trash skimmer boat

Sedangkan terdapat satu garis lurus yaitu garis yang menyatakan buttock line. Gambar 9 merupakan bagian half breadth merupakan gambar irisan-irisan kapal tampak atas, pada setiap garis air (water line) yang digambar dengan setengah lebar kapal.

\section{Rencana Umum}

Sebelum mendesain rencana umum terlebih dahulu maka dilakukan perhitungan displacement atau berat kapal. Pada perhitungan berat kapal trash skimmer boat ini, ada dua hal utama yang dihitung yaitu LWT (Light Weight Tonnage) dan DWT (Dead Weight Tonnage). Keduanya hal tersebut memiliki elemen yang berbeda beda dan apabila dijumlahkan akan menjadi berat total kapal. LWT dan DWT ditampilkan pada Tabel 8 dan Tabel 9.

Menghitung koreksi displacement (Tabel 10) dilakukan setelah mengetahui total berat dari DWT 
dan LWT dari kapal. Selisih antara displacement dan jumlah dari DWT dan LWT dari trash skimmer boat ini ditentukan tidak lebih dari $5 \%$.

Rencana umum dapat didefinisikan sebagai perencanaan ruangan yang dibutuhkan sesuai dengan fungsi dan perlengkapan kapal. Pembuatan rencana umum dilakukan setelah pembuatan rencana garis karena outline kapal yang digunakan pada gambar rencana umum didapatkan dari gambar rencana garis. Langkah awal dalam pembuatan rencana umum adalah menggambar outline badan kapal tampak atas, tampak samping, dan tampak depan kapal sesuai dengan lines plan yang telah dibuat. Pada perhitungan titik berat sebelumnya telah dilakukan perencanaan peletakan tangki-tangki, perencanaan tersebut digambarkan di rencana umum sesuai dengan perhitungan.

Tabel 8. Rekapitulasi berat LWT kapal

\begin{tabular}{lcc}
\hline \multicolumn{1}{c}{ Komponen } & Berat & Keterangan \\
\hline Berat Sampah & 0.12 ton & Asumsi 1 orang dengan berat \\
Berat Crew dan Barang & 0.15 ton & $80 \mathrm{~kg}$ \\
Bawaen & 0.000 ton & \\
Berat Fuel Oil & 0.00000 ton & \\
Berat Lubrication Oil & & \\
\multicolumn{1}{c}{ Total } & 0,271 ton & - \\
\hline
\end{tabular}

Tabel 9. Rekapitulasi berat DWT kapal

\begin{tabular}{lcc}
\hline \multicolumn{1}{c}{ Komponen } & Berat & Keterangan \\
\hline LWT & 0.420 ton & - \\
DWT & 0.271 ton & - \\
Total & 0.691 ton & - \\
Displacement & 0.697 ton & hasil maxsurf pada sarat 0.37 \\
Displacement-(LWT+DWT) & 0,006 ton & + \\
$\quad$ Correction & $0,89 \%$ & - \\
\hline
\end{tabular}

Tabel 10. Koreksi displacement

\begin{tabular}{lll}
\hline Komponen & Berat & Keterangan \\
Aluminium & 0.128 ton & Margin 20\% \\
Berat Geladak Kapal & 0.052 ton & - \\
Berat Konstruksi Kapal & 0.036 ton & - \\
Berat Outboard Motor & 0.027 ton & - \\
Berat Peralatan dan Perlengkapan & 0.156 ton - \\
Berat Ruang Navigasi & 0.008 ton - \\
Total & 0.420 ton -
\end{tabular}

Pada rencana umum dari trash skimmer boat ini terdapat 4 roller yang berperan sebagai dapra pada umumnya dan berbahan karet. Digunakan agar badan kapal tidak rusak saat kapal mengambil sampah yang berada pada pesisir sungai. Gambar 10 menunjukkan main deck kapal.
Terdapat satu mesin outboard (Gambar 11) dan mesin outboard ini digunakan karena pada trash skimmer boat tidak membutuhkan mesin yang besar dalam pengoperasiannya. Kapal ini juga memiliki satu mini crane yang dioperasikan untuk memindahkan sampah dari keranjang kapal menuju tempat pembuangan sampah. Dan mini crane ini memiliki kapasitas angkut hingga $168 \mathrm{~kg}$.

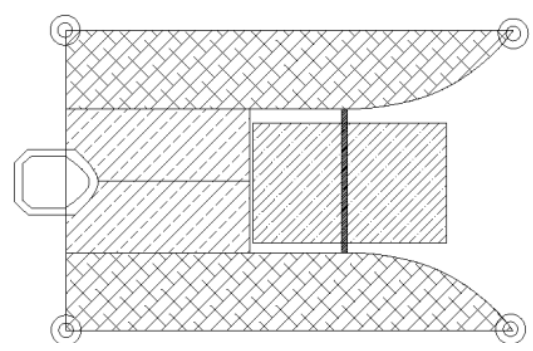

Gambar 10. Main deck trash skimmer boat
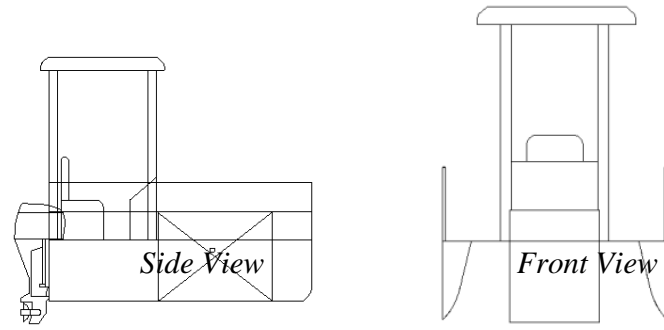

Gambar 11. Side dan front view trash skimmer boat

\section{KESIMPULAN}

Berdasarkan hasil penelitian yang telah dilakukan maka hasil dari penelitian ini adalah setelah dilakukannya perancangan dengan metode Parent Design Approach maka diperoleh panjang kapal sepanjang $3 \mathrm{~m}$ dengan lebar kapal $1.8 \mathrm{~m}$ serta tinggi $1.38 \mathrm{~m}$. Sarat sebesar $0.38 \mathrm{~m}$. Jumlah sampah yang harus diangkut kapal dalam sehari sebanyak $15.1 \mathrm{~kg}$. Kapal ini memiliki fasilitas satu unit keranjang sampah dengan kapasitas muatan sebesar $168 \mathrm{~kg}$ dan dibantu dengan satu unit mesin outboard sebesar 6 PK dalam menunjang operasional kapal ini.

\section{DAFTAR PUSTAKA}

Arianto, W. (2016). Desain Kapal Wisata Katamaran untuk Kepulauan Karimunjawa. Surabaya: Institut Teknologi Sepuluh Nopember.

Badan Lingkungan Hidup. (2015). Laporan Status Lingkungan Hidup Kota Balikpapan Tahun 2015. Retrieved from http://dlh.balikpapan.go.id/assets/filedownload/B UKU_Laporan_SLHD_2015.pdf 
Desain Skimmer Boat (Kapal Pengambil Sampah) Daerah Perairan Sungai di Kalimantan Timur (Amalia Ika Wulandari, Wira Setiawan, Taufik Hidayat dan Arman Fauzi)

Badan Pusat Statistik Kota Balikpapan. (2018). Retrieved from https://balikpapankota.bps.go.id/publication/201 8/08/16/8df63ffd73378cb97b4fc3eb/kota-balikp apan-dalam-angka-2018.html

Chrismianto, D., Adietya, B. A., \& Sobirin, Y. (2014). Pengaruh Variasi Bentuk Hull Kapal Catamaran. KAPAL: Jurnal Ilmu Pengetahuan \& Teknologi Kelautan, Vol. 11(2), 99-106.

Dubrovsky, V., \& Lyakhovitsky. (2001). Multi-Hull Ships. Rusia: Backbone Pub. Co.
Insel, M., \& Molland, A. F. (1991). An Investigation into the Resistance Components of High Speed Displacement Catamarans. The Royal Institution of Naval Architects, 1-20.

Jamaluddin, A., Utama, I. K., Widodo, B., \& Molland, A. F. (2012). Experimental and Numerical Study of the Resistance Component Interactions of Catamarans. Journal of Engineering for the Maritime Environment, Vol. 227 (1), 51-60.

Walezyk, S. L. (2006). Patent No. US20060065586A1. United States. 